\title{
AS IMAGENS-CINEMATOGRÁFICAS COMO FORÇA QUE IMPULSIONA O DEVIR-PENSAMENTO NO COTIDIANO ESCOLAR
}

Sandra Kretli Silva ${ }^{1}$

\section{INTRODUÇÃO: O QUE PODE UMA IMAGEM CINEMATOGRÁFICA EM ENCONTROS DE FORMAÇÃO DE PROFESSORAS?}

Este artigo constitui-se de parte dos resultados de uma pesquisa de pós-doutoramento que investigou o que pode uma imagem-cinema nos encontros de formação de professoras. ${ }^{2}$ Spinoza (2014) aponta que a experiência a ninguém ensinou o que pode um corpo. O autor sugere que, para descobrirmos a potência de um corpo, é preciso que estejamos atentos ao seu poder de afetar e de ser afetado e de como se interage e experimenta com outros corpos. Assim, com base em Spinoza (2014) e Deleuze $(2015,2016)$, problematizamos a força das imagens-cinema nos encontros de formação de professoras e a pesquisa com o cotidiano escolar como potência para o movimento de pensamento que se produz em redes de conversações (CARVALHO, 2009), a fim de capturar os afetos que emergem do encontro com essas imagens e o modo como essas afecções promovem novas invenções curriculares e a criação de outros modos de aprenderensinar ${ }^{3}$ e de fazer pesquisa no campo do currículo.

Os encontros com as professoras ${ }^{4}$ foram realizados em dois Centros Municipais de Educação Infantil (Cmeis), localizados na capital do Espírito Santo, Vitória. Como disparador inicial para as redes de conversações com as professoras, selecionamos o premiado curta-metragem Alike para

\footnotetext{
${ }^{1}$ Professora Adjunta do Departamento de Teorias e Práticas do Ensino da Ufes e do Programa de Pós-Graduação em Educação Mestrado Profissonal em Educação (PPGMPE)

$2 \mathrm{O}$ estudo nasce impulsionado pelos fluxos e forças do projeto de pesquisa e de extensão "Filmes e conversas: por uma estética dos encontros", que teve início em 2013 e foi ressignificado e impulsionado com o movimento de pósdoutoramento.

3Como Alves (2003), utilizaremos, neste texto, algumas palavras juntas, com o intuito de marcar a necessidade de superarmos algumas dicotomias herdadas do período no qual se "construiu" a ciência moderna.

4Utilizaremos encontros de formação de professoras sempre no feminino, porque somos em maioria mulheres nas escolas. No entanto, em todas as instituições investigadas, tivemos a participação de professores, o que só engrandece o nosso trabalho.
} 
provocar o pensamento. Isso porque Alike possui signos ópticos e sonoros capazes de quebrar os clichês e violentar o pensamento, provocando o deslocamento de um modo de pensar o conhecimento e os processos de aprender ensinar de forma padronizada, unificada, convergente à epistemologia moderna/positivista. O curta-metragem Alike possibilita, também, problematizar a tentativa de fiscalização e de controle da vida por meio do tempo cronológico que, muitas vezes, dificulta os processos de criação, de resistência, inventividade, de alegria e, principalmente, de vida intensiva no cotidiano escolar.

As enunciações, gestos e sentimentos foram registrados em imagens fotográficas, fílmicas e imagens sonoras que, posteriormente, foram transcritas no diário de campo e se apresentam entremeadas a este texto como agenciamentos da força de ação coletiva, capazes de problematizar e reinventar os espaçostempos da educação infantil e de inventar novas possibilidades epistemológicas e metodológicas para as pesquisas curriculares.

Spinoza (2014) afirma que o corpo é capaz de muitas coisas que surpreendem a nossa existência. Com base nesse autor, questionamos: podem as imagens cinematográficas nos surpreender? Podem as imagens cinematográficas em um encontro de professoras provocar rupturas no pensamento dogmático abrindo brechas para o pensamento nômade fluir e fruir nas escolas? Que afecções insurgem quando, em um encontro de professoras, são acionadas imagens cinematográficas? Os encontros com essas imagens ativam a potência da ação coletiva, ampliando a criação de novos modos de pensar e de fazer pesquisa no campo curricular? Fazem movimentar as invenções curriculares e os processos de aprenderensinar?

Sobre a origem, a natureza e a potência dos afetos, Spinoza (2014) argumenta que um corpo pode ser afetado de muitas formas. Nessa afetação, a potência de ação de um corpo pode aumentar ou diminuir; também pode não se alterar. O que provoca as alterações da nossa potência de agir são as afecções dos corpos, os encontros, as relações. Se as afecções acionam bons encontros que expandem a potência de agir, ficamos alegres. Do contrário, se temos encontros tristes, reduzimos a potência de nosso corpo. Entretanto, ninguém ainda conseguiu explicar todas as funções e tudo do que o corpo é capaz.

Essa impossibilidade de definir todas as potencialidades do corpo e de deixar aberturas para que novas im/possiblidades sejam inventadas viabiliza a expansão e a infinitude do pensamento e dos processos inventivos sobre o que pode um corpo. E quanto às imagens-cinema? Que movimentos intensivos e inventivos essas imagens irrompem? As imagens cinematográficas seguidas de redes de 
conversações com as professoras expandem as múltiplas formas de conhecimentossignificações, possibilitando inventarmos novos modos de fazer pesquisa?

Apresentamos neste artigo, portanto, uma análise de como e em que sentido o encontro com as imagens do curta-metragem Alike, artefato disparador das redes de conversas (CARVALHO, 2009) entre as professoras, provocou deslocamentos de pensamentos, fazendo expandir, por meio das forças ativas, os "bons encontros" que impulsionam a potência de ação coletiva e a formação inventiva na escola. Desse modo, este artigo mostra os modos como o encontro das professoras com as imagens do curta Alike arrancou dos clichês uma nova imagem para as escolas, para as pesquisas no campo do currículo e para as infâncias.

Para isso, buscamos, inicialmente, problematizar, com base sobretudo nos escritos de Deleuze (2010, 2015, 2016) e Spinoza (2014), a potência das imagens cinematográficas nos encontros de formação de professoras. Em seguida, apresentaremos os afetos que pediram passagem nos encontros com as imagens do curta-metragem Alike, para pensarmos como e em que sentido essas imagens atuam como força nas redes de conversas, expandindo os processos inventivos e a potência de ação coletiva das escolas.

O argumento aqui desenvolvido, portanto, é o de que o encontro com as imagens cinematográficas pode movimentar o pensamento das professoras, pode ser um novo ar para as escolas, um oxigênio para ampliar a formação inventiva, os movimentos curriculares e os processos de aprenderensinar e de pesquisar. Pode, ainda, produzir sensações e questionamentos que auxiliam a fazer rupturas com as "verdades" que foram construídas/produzidas para as escolas, para as infâncias, para as docências, para os currículos, para as pesquisas em educação. É isso que mostraremos a seguir.

\section{O QUE PODE A IMAGEM?}

Estamos cercados de imagens por todos os lados e de experiências imagéticas que possibilitam encontros com diferentes linguagens e afecções, produtoras de pensamento e de conhecimentos. Silvio Gallo (2014), com base em Levy (1998), argumenta que a comunicação hoje é imagética e discute duas formas/forças das imagens: a primeira - é que a imagem informa e, portanto, é palavra de ordem. Como palavra de ordem, ela não é pensamento, mas, sim, informação, conformação, representação, repetição, recognição. Para abrir outra possibilidade para a imagem, o autor questiona se ela pode devir-pensamento. 
A imagem como informação, palavra de ordem, ainda é recorrente nos espaçostempos escolares. Reforça, assim, a ideia de imagem como representação, repetição, ou seja, prevalece a lógica da recognição, da reprodução, do pensamento dogmático, que costuma habitar as ideias universais. Nessa perspectiva, o pensamento tomado como representação é o pensamento com imagem, centrado no conceito de identidade e que remete a diferença ao erro.

Deleuze (2006) insiste na busca de uma filosofia da diferença que rompa com o pensamento como representação. Investe no pensamento como criação, que possa pensar o novo, o im/pensável, o diferente - o pensamento nômade. Para isso, faz-se necessário investir em um pensamento sem imagem. Um pensamento que escapa, que experimenta, que inventa.

Gallo (2014) ressalta que, para Deleuze, a obra de arte não informa, não produz palavras de ordem, repetição, recognição; ela expressa e provoca sensações, emoções. Assim, como imagemsensação, portanto, ela incita o pensamento, provoca a invenção e a criação. A potência do pensamento se constitui quando a "[...] imagem não representa nada; ela é sensação pura, puro sentido produzido na relação. E, na afecção que produz no sujeito, incita o pensamento" (GALLO, 2014, p. 19).

De tal modo, lançamos, ainda com Gallo (2014), novas provocações para a pergunta: o que pode a imagem? Será que o excesso de informações e fluxos de imagens entorpece, anestesia, acelera, energiza o nosso pensamento? No encontro com as professoras de educação infantil, esse questionamento do excesso de imagens nas nossas vidas também foi problematizado. Elas ressaltam que, do mesmo modo que as imagens vêm sendo utilizadas como "calmante", para quietar as crianças, elas têm provocado, também, muita inquietação e agitação, pois as crianças, em alguns momentos, chegam às escolas absolutamente confusas com o excesso de imagens, precisando de espaçotempo de aconchego e de conversa. As crianças, os jovens e também os adultos estão, cada vez mais, envolvidos em um mundo imagético meramente informacional, assim, falta mais tempo para conversar, pensar, criar coletivamente e se relacionar.

A infância do pensar abre as portas ao impensável (KOHAN, 2005). Com base em Badiou (1996), Kohan (2005) afirma que a potência de um pensamento é ser infinito e manter-se desabrigado, pois assim haverá sempre a possibilidade de renovação e de reinvenção. Ou seja, para pensar, faz-se necessário violentar o pensamento, sacolejar, forçar a pensar, deslocar, desterritorializar. Pensar é um encontro e, para encontrar uma linha de fuga para escapar de tudo aquilo que o quer aprisionar/sufocar, o pensamento vai procurando fissuras, um novo ar para respirar. Nesse sentido, o acompanhamento de processos por meio de cartografia no cotidiano escolar é uma potência para a 
expansão de "[...] redes sociais, de comunidades, de formas de vida: produção de subjetividade e, portanto, de possível exercício micropolítico" (CARVALHO, 2008, p. 136).

\section{A CARTOGRAFIA DA EXPLOSÃO DE PENSAMENTOS QUE EMERGEM POR MEIO DO ENCONTRO COM AS IMAGENS CINEMATOGRÁFICAS DO CURTA ALIKE}

LUZES APAGADAS

O ENCONTRO COM ALIKE: VIDA, APRENDIZAGEM, INVENÇÃO
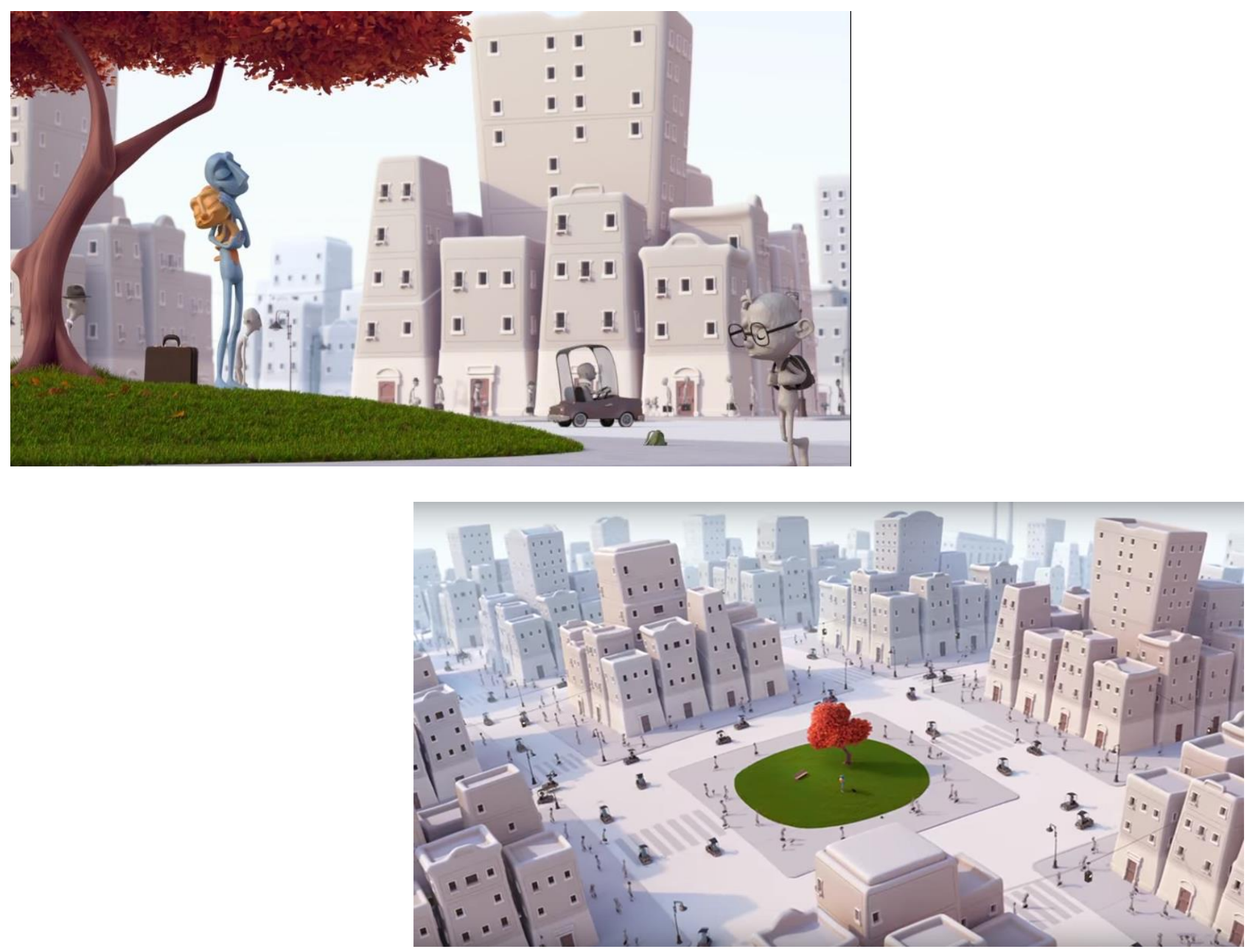

https://www.youtube.com/watch?v=UATPH44jRSw

O primeiro curta-metragem selecionado para o encontro com as professoras foi $\operatorname{Alike}^{5}-$ uma animação de apenas oito minutos, dirigida pelos espanhóis Daniel Martínez Lara e Rafa Cano 
Méndez. Trata da relação de pai e filho diante dos desafios de viver em uma sociedade disciplinadora e produtivista. Paste, o filho, demonstra ser uma criança feliz, saltitante, observadora, curiosa e criativa. Copi, o pai, era um homem afetivo, trabalhador, atencioso e cuidadoso com o filho. Aparentemente estava cansado da rotina, estressado com o seu acúmulo de trabalho repetitivo e completamente preso às responsabilidades cotidianas. Copi procura ensinar e conduzir o filho para seguir as regras e normas da escola.

Nesse contexto, Paste vai se tornando uma criança triste, sem cor e sem graça, ao se sentir impedido de inventar e de sentir a beleza, as cores e a pluralidade do mundo. Ao ser submetido a exercícios sem sentido e repetitivos, ele vai perdendo a sua força inventiva e intensiva e passa apenas a responder ao que a escola lhe propõe.

Nesse momento uma tela preta entra em cena, o que provoca uma pausa no filme, um deslocamento no movimento no pensamento. Pausa para lembrar que o capitalismo, em sua nova versão, além de explorar a nossa força de trabalho, vem tentando se apropriar da vida, de sua potência de criação e cooperação (ROLNIK, 2018). Em seguida, Copi, ao perceber as mudanças em Alike, problematiza a vida e, junto com o filho, por meio de um forte abraço, desenquadra. Resgata a alegria, a arte e a força intensiva de toda a cidade, liberando, portanto, a vida, a cor, a potência de ação coletiva, que faz expandir " [...] as redes de saberesfazeres e valores presentes nas realidades cotidianas dos diferentes espaçostempos de prática social” (OLIVEIRA; SGARBI, 2008, p. 83) e possibilita a criação de novos modos de interação social, novas crenças e valores que foram muitas vezes invisibililizados pela hegemonia do pensamento moderno.

Alguns atravessamentos dessa animação foram tomados como destaque pelas professoras: a contraposição entre os diferentes tempos, ou seja, o tempo cronológico e o tempo intensivo, inventivo - o tempo redescoberto; a responsabilidade com o trabalho e o deslocamento causado por meio dos signos artísticos, ou seja, pelo encontro com a música produzida pelo violinista. Os gestos e os ritmos da arte provocam rupturas no pensamento que fazem problematizar os processos de criação e a repetição, a fronteira, os entrelugares.

As professoras afirmam também que, na hora da pausa, em que o cineasta apresentou a tela escura, a não imagem, foi possível criar novas imagens de pensamento e, assim, alguns possíveis para os personagens, para o enredo, estabelecendo relações com a própria vida. Por fim, comentam sobre a tentativa do pai de Alike de retomada da criação por meio da força da relação; sobre a potência da

\footnotetext{
não deixem de ver a animação e, se possível, nos escrevam contando que afetos pediram passagem por meio das afecções provocadas pelo encontro.
} 
arte do encontro, do abraço que fortalece e rompe com a repetição que aprisiona a alma, que nos enfraquece e provoca adoecimento e morte. A música encanta, embala, alegra e retoma o tempo afetivo. Vida que volta a pulsar, a movimentar-se, a reinventar-se.

Nos encontros com as imagens cinematográficas nas formações de professoras, nada é antecipado. Deixamos as imagens agir, falar, fluir, violentar o pensamento, pois a nossa intenção é que as imagens nos deem a falar, nos façam pensar, provoquem o desalojar do pensamento, pois, como afirma Deleuze (2003, p. 29): “[...] mais importante que o pensamento é 'aquilo que faz pensar'". Assim, quando o filme acaba, as luzes se acendem. Às vezes, fica o silêncio, as emoções, as inquietudes, até que uma enunciação puxa a rede de conversações e as professoras apresentam os afetos (tristes ou alegres) que os encontros com as imagens do curta Alike causaram em seus corpos.

\section{LUZES SE ACENDEM: REDES DE CONVERSAÇÕES - EXPANSÃO DA POTÊNCIA DE AÇÃO COLETIVA}

As imagens da animação Alike possibilitaram agenciamentos e mapas intensivos ${ }^{6}$ das professoras, que, provocadas pelas afecções causadas pela força das imagens, verbalizam o desalojar do pensamento, buscando algumas fissuras nas linhas molares (nas normatizações, prescrições curriculares etc.) da escola, abrindo os possíveis para a expansão das micropolíticas e resistências cotidianas.

Deleuze (2011, p. 88) afirma que a arte faz mapas extensivos e intensivos, pois é feita de trajetos e devires. "[...] um devir não é imaginário, assim como uma viagem não é real. É o devir que faz do mínimo trajeto ou mesmo de uma imobilidade no mesmo lugar, uma viagem; é o trajeto que faz do imaginário um devir". Os mapas dos trajetos e dos afectos remetem um ao outro. Nesse contexto, fomos mapeando os trajetos e afectos engendrados nas redes de conversações com as professoras, a fim de potencializar o espaço de formação coletiva, que se constitui com o compartilhamento de experiências plurais em redes de sociabilidade e de solidariedade. Não apresentaremos os nomes das educadoras, pois entendemos essas enunciações como devires afetivos de corpos coletivos que se conectam problematizando e reinventando as escolas cotidianamente em suas redes de poderes, saberes e subjetividades.

"Sabe o que mais me afeta com essas imagens? O que pensamos quando estamos vindo para
a escola? Em aprendizagem, mas aprender o quê, para quê? Não podemos perder de vista a
questão da vida. Como articular a aprendizagem com o lúdico, as brincadeiras e as fabulações
dos alunos, principalmente, na educação infantil? Estamos com um projeto este ano que é

6 Para Deleuze (2011), os mapas não podem ser compreendidos apenas em extensão ou constituídos por trajetos, pois existem mapas de intensidade, mapas de densidade, que dizem respeito ao que preenche o espaço, ao que subentende o trajeto. Uma lista de afectos, constelação ou devir é, portanto, um mapa intensivo. Por isso, as enunciações apareceram entremeadas ao texto, como devires que pediram passagem. 
sobre as invencionices das crianças, exatamente objetivando não tornar o espaço da escola cansativo, tão cinza".

A partir das afecções causadas pelas imagens e dos afetos que eram suscitados nas redes de conversas, problematizamos os processos de aprendizagem e de ensino, a função da escola, os movimentos inventivos curriculares, a sociedade, os processos de produção de subjetividades, as relações de poder, as redes de solidariedade, a amizade, as resistências, as re/existências. Assim, as professoras, coletivamente, apostam nas suas produções criadas nos encontros com os alunos, reafirmam a importância do trabalho em parceria, nas trocas cotidianas que, conforme aponta Carvalho (2009, p. 189), se efetivam por meio de conversações com participação ativa e criativa que combina duas dimensões: “[...] a poética da participação e a sociabilidade, articulando vozes, assuntos, de modo que tornem possível a multiplicidade partilhada - conversação recriada aberta e inacabada".

\begin{abstract}
"Eu achei muito interessante essa animação, pois leva-nos a problematizar como as escolas cerceiam a criatividade das crianças, por meio das prescrições, do controle e pelas imposições regulamentares. Isso nos leva a questionar o sentido das escolas para as crianças e adultos. Sabe aquela cena em que o menino vai, aos poucos, parando de ver as cores? Ela demonstra os sentimentos que a criança pode vir a ter quando se depara com tantas repetições sem a possibilidade de interagir com as suas ideias e desejos. Isso afeta a sua alegria. Assim, a criança vai se entristecendo à medida que a sua inventividade vai sendo cerceada pelas imposições do sistema escolar".
\end{abstract}

Logo que as professoras verbalizavam sobre os modos como as imagens as afetavam e possibilitavam o desalojar do pensamento, todo o conjunto de justas ideias (DELEUZE, 2010) que, de algum modo, se instalava naquele coletivo ia se decompondo e fazendo emergir e extrair daí justo ideias. Seguindo essa linha ativa e criadora, as professoras questionam o modelo formal da escola e se permitem, por meio da imaginação, invenção, tornar o verdadeiro indecidivel, fazendo com que as imagens se tornassem, portanto, devir-pensamento.

Vivemos engendrados a linhas de articulação ou segmentaridade, estratos, territorialidades, mas também a linhas de fuga - linhas de intensidade que traçam os movimentos de desterritorialização e desestratificação, fazendo-nos escapar das tentativas totalizadoras e de modelização (DELEUZE; GUATTARI, 2012). Há muitas linhas de segmentaridade dura: a família, a escola, o trabalho, a profissão, as reformas, as legislações, as diretrizes curriculares, enfim. As linhas moleculares são de segmentaridade mais flexíveis, por isso possibilitam as pequenas modificações, os desvios.

Essas linhas de naturezas diferentes seguem múltiplas direções e traçam processos que estão sempre em movimento e em constante transformação. As forças que são colocadas em 
praticasdiscursivas agenciam as tensões, as contradições e as conexões nas/das múltiplas redes de poderes, saberes e de subjetivações. Que forças fazem movimentar as linhas de vida de professoras? As imagens cinematográficas nos encontros com as professoras desestabilizam essas linhas, violentam o pensamento, produzem efeitos ativos, ${ }^{7}$ suscitando novas ideias nas redes de conversas das professoras?

Vale ressaltar que as linhas de articulação são inseparáveis, ou seja, elas se engendram, coexistem e se embaralham. Nesse contexto, os autores defendem que tudo é político e que toda política é, ao mesmo tempo, macro e micropolítica. Portanto, apostamos com esses autores que “[...] uma micropolítica da percepção, da afecção, da conversa” (DELEUZE; GUATTARI, 2012, p. 99) opera fazendo microfissuras, que fazem escapar às organizações binárias a máquina de sobrecodificação e as tentativas de controle. Por isso a nossa aposta no uso das imagens cinematográficas como elemento disparador para expandir as redes de conversações com as professoras, a fim de desalojar os clichês educacionais, potencializar as invencionices nas escolas, fazendo insurgir, nos movimentos curriculares, linhas de fuga, processos de resistências e de (re)existência às tentativas de controle e de padronização.

Assim, cartografamos o modo como os movimentos de invenção e de criação desse corpoescola que se fazem e refazem, em processos de interação combinação e conexão, acompanhando os fluxos das forças intensivas e dos agenciamentos que expandem a potência de ação coletiva. Nesse contexto, fomos acompanhando os processos de territorialização, desterritorialização e de reterritorialização, ${ }^{8}$ problematizando os silêncios, as experimentações, os choros coletivos, as certezas e tristezas, as alegrias, as redes de solidariedade, os conflitos - a multiplicidade, a diferença.

Como se constituíram esses encontros das professoras com as imagens? Como capturar a potência dos encontros? Em momentos anteriores, fomos convidadas por uma dessas escolas a pensar com as professoras a reconstrução do Projeto Político-Pedagógico (PPP). A partir desses encontros iniciais, propomos alguns deslocamentos de rotas e, assim, coletivamente, fomos tentando introduzir a gagueira criadora proposta por Deleuze (2010), fazendo o "E” arrastar todas as relações $e \ldots e . . . e .$. Nesse processo, fomos acompanhando os afetos que pediam passagem, usando e abusando do

\footnotetext{
7 Os efeitos ativos são entendidos como produção coletiva, força de ação que se constitui em devires e na grupalidade. 8 Para Deleuze e Guattari (2012), não há território sem aberturas, linhas de fuga, vetores de saída. A desterritorialização ocorre por meio dos movimentos criados pelos agenciamentos na operalização das linhas de fuga e a reterritorialização se constitui como novos agenciamentos maquínicos de corpos e coletivos de enunciação. Vale ressaltar que, sempre que houver movimento de desterritorialização, haverá movimento de reterritorialização, ou seja, esses processos são indissociáveis.
} 
estrangeiro da língua, para que os infinitos verbos ser, destinados às escolas, operassem ativamente, tornando-se múltiplos.

Assim, o corpo vibrátil ${ }^{9}$ atravessava o cotidiano escolar em desejo de encontros, de inusitados, de imprevistos, de acontecimentos, de fabulações. Os possíveis e os (in)possíveis para a reinvenção cotidiana das escolas se deflagravam junto com as surpresas e as fabulações que emergiam quando as professoras e as imagens entravam em relação.

Uma professora relata que, no fim do dia, na hora da roda final, um aluno mencionou: "Professora, na minha casa tem um túnel e tem sereia". "É mesmo? E a sereia canta?”, questiona a professora. Ela complementa: "Impressionante que eu só pude parar para fabular com o meu aluno nesse momento. Como eu preciso dar linha para essas fabulações dos alunos! Eu só pude pensar isso por conta desse encontro com as imagens do Alike”. Para Deleuze (2003), só buscamos a verdade ou problematizamos a imagem-representação, quando sofremos uma espécie de violência que nos impulsiona a buscar uma nova imagem, um novo pensamento. Portanto, há sempre a violência de um signo que nos que nos rouba a paz, que nos desestabiliza, que nos força a pensar. Assim, “[...] o signo que é objeto de um encontro e é ele que exerce sobre nós a violência" (DELEUZE, 2003, p.15).

Deleuze (2003) afirma que nunca se sabe como uma pessoa aprende, mas, de qualquer forma que se aprenda, não será pela assimilação de conteúdos e objetivos: é sempre por meio dos encontros com os signos. O pensamento precisa ser forçado a buscar o sentido do signo. Cada espécie de signo corresponde a uma linha de tempo privilegiada, porém uma mesma linha de tempo mistura várias espécies de signos. Os signos mundanos sugerem um tempo que se perde; o signo do amor envolve um tempo perdido; os signos sensíveis muitas vezes nos fazem redescobrir o tempo, restituindo-o no meio do tempo perdido; o signo da arte promove o encontro com o tempo redescoberto - tempo original absoluto que compreende todos os outros tempos. Para Machado (2009, p. 197), a tese central de Deleuze ao buscar a relação entre signo e pensamento: “[...] é o encontro contingente com o que força a pensar que produz a necessidade de um ato de pensamento; fazendo violência ao pensamento, os signos forçam a pensar ou a buscar o sentido".

De acordo com Deleuze (2010), no cinema, as imagens são signos. O cinema faz nascer signos que lhes são próprios, mas, uma vez criados, eles voltam a irromper em outro lugar. Assim o mundo se coloca a fazer cinema, e nós nos constituímos cineastas dos nossos tempos. Deleuze (2010, p. 90) acredita em dois regimes de imagem: o da imagem-movimento, "[...] que opera por cortes racionais

\footnotetext{
9 Corpo sensível, pulsante e intensivo que se coloca aberto à expansão da vida.
} 
e encadeamentos, e que projeta ele mesmo um modelo de verdade (a verdade é o todo...)"; e o da imagem-tempo, que é um regime cristalino, que procede por cortes irracionais e só tem reencadeamentos. Nesse regime de imagem, no lugar de um modelo de verdade, há a potência do falso como devir, a vontade de potência. Ao pensar a imagem-movimento e a imagem-tempo, Deleuze trata de dois tipos de narrativa e de duas formas de se relacionar com o tempo: o cinema clássico representa indiretamente o tempo; já o cinema moderno apresenta o tempo diretamente, ou seja, quando o cinema de ação dá lugar ao cinema de vidência.

Assim, cada cineasta constrói à sua maneira essa imagem do todo, essa imagem do tempo. Então questionamos: que imagens estamos produzindo nas/das escolas? Que imagens estamos produzindo de nós mesmos?

Deleuze (2015) questiona por que Zavattine conceitua o neorrealismo como uma arte dos encontros, dos encontros efêmeros. $\mathrm{O}$ autor esclarece que os encontros podem tomar formas muito diferentes, atingir o excepcional ou manter-se na mesma fórmula. Exemplifica citando a história da jovem criada que entra de manhã na cozinha e faz seus serviços cotidianos com uma série de gestos repetitivos, mecânicos e cansados: “[...] Limpa um pouco, espanta as formigas lançando-lhes água, pega no moinho de café, fecha a porta com a ponta do pé. E quando os seus olhos se cruzam com o seu ventre de grávida, é como se fosse nascer toda a miséria do mundo" (p. 8). No percurso de uma série de gestos insignificantes, que obedecem a esquemas sensório-motores simples, o que aparece, inusitadamente, é uma situação óptica pura, que faz tornar sensíveis o tempo e o pensamento, tornálos visíveis e sonoros, de tal modo, que a jovem não tem mais resposta ou reação.

\footnotetext{
Na banalidade cotidiana, a imagem-ação e até a imagem-movimento tendem a desaparecer em favor de situações ópticas puras, mas estas revelam ligações de um tipo novo que já não são sensório-motoras e que põem os sentidos emancipados numa relação directa com o tempo, com o pensamento (DELEUZE, 2015, p. 33).
}

O curta-metragem Alike possibilita pensar novos possíveis para a docência, para os currículos, para os processos de aprenderensinar e para as pesquisas no campo curricular. Para Deleuze (2003), ser sensível aos signos, entender o mundo como signos a serem decifrados é um dom, mas, se não houver os encontros necessários, esse dom corre o risco de permanecer oculto em nós. Para ele, cada signo possui duas metades: representa um objeto e, ainda, significa alguma coisa diferente: "Passamos ao largo dos mais belos encontros, nos esquivando dos imperativos que deles emanam: ao aprofundamento dos encontros, preferimos a facilidade das recognições" (2003, p. 26). No entanto, quando somos surpreendidos e temos o prazer de experimentar o explendor de um signo, “[...] só 
sabemos dizer 'ora, ora, ora' o que vem a dar no mesmo que 'bravo, bravo, bravo', expressões que manifestam nossa homenagem ao objeto" (p. 26).

Percebemos que, no início das conversas, logo que as luzes acendiam, as primeiras enunciações expressas pelas professoras buscavam a interpretação e tradução das imagens, uma tentativa de decifrar os signos. Mas, à medida que a conversa esquentava, surgiam, também, as emoções, expressões de sentimentos ainda inexplicáveis que o encontro com as imagens do curta Alike suscitara. Novos olhares, escutas, iam fazendo com que aquelas imagens fossem repensadas, remodeladas, trazendo outros possíveis, novos sentidos para as imagens, para as infâncias, para as pesquisas curriculares e para o cotidiano escolar.

\begin{abstract}
"Penso que as imagens das crianças que vão se tornando cinzas, por excesso de disciplinação que o filme retrata, em alguns momentos, tem sido substituídas pelas cores alucinantes, fluorescentes, próprias de reações psicotrópicas, superexcitações. Hoje, no tumulto do nosso dia, estamos muito acelerados. Durante a manhã, tive que falar para a minha colega: tome uma água, respire. É claro que combinamos muitas coisas para além da água [risos]”.
\end{abstract}

Nesse momento, as professoras se entreolham e, assim, reafirmam e reforçam a parceria cotidiana. Percebemos, nessa cumplicidade estabelecida, o quanto é necessário estar junto, produzir junto, criar coletivamente: “[...] Então, temos que pensar onde está o oxigênio para gente suportar, precisamos buscar o oxigênio", ressalta a professora. Então, eu pergunto: "O que tem sido o oxigênio para vocês, onde está esse oxigênio, essa força cotidiana?". As professoras respondem:

\footnotetext{
"A força está quando uma apoia o trabalho da outra, quando pedimos apoio às pedagogas e colegas na hora das inúmeras dificuldades e encontramos escuta [...]"."Precisamos viver sem pressa, para interagirmos mais e melhor. Penso que a força está na interação". "[...] Hoje tinha quatro mães me esperando para bater um papo. Aí, sim, a vida parece que volta a fluir entre os humanos. Vamos viver o outono, gente!".
}

A professora retoma outro signo artístico usado antes de darmos início à apresentação do curta. Era um poema escrito por uma delas que prefere se manter no anonimato. O poema voltou a ressoar, nesse momento, como um devir afetivo que pedia passagem para o respiro cotidiano, para o pedido de levar a vida com menos pressa e com mais possibilidades de capturar novas cores, cheiros e intensidades: "É quase outono. Que se feche o maçarico desse verão. Outono é se ver de dentro, quieto, imerso na seiva outonal. As cores dessa estação são as mais bonitas. Pare e veja, pare e seive" (DIÁRIO, 2019).

Um novo fio foi puxado para a rede de conversas. As afecções causadas pelas imagens do filme, expostas nas redes de conversas das professoras, possibilitaram um pedido de alerta expresso 
no poema de uma professora: por mais silêncio, por mais vazios para que possamos torná-los cheios de invencionices de crianças e de professoras. Por mais encontros, mais conversas, mais outonos, mais renova-ação para que possamos respirar um novo ar e produzir, assim, novas imagens para as escolas.

\begin{abstract}
“O curta me possibilitou pensar que a cidade tem encantos e que a educação não acontece só na escola; ela pode e precisa estar em diversos lugares e ser pensada com outras linguagens. A cidade também é lugar de educação. O aluno foi percebendo a resposta que esperavam dele e foi respondendo, mas perdendo a sua criatividade. A gente já sabe que é preciso ouvir as enunciações infantis, mas quase não conseguimos escutar. $\mathrm{O}$ filme nos alerta para escutarmos mais as crianças".
\end{abstract}

O encontro com as imagens cinematográficas possibilita uma análise das relações de forças que atravessam as vidas das professoras, das crianças e dos movimentos curriculares de forma qualitativa e não quantitativa, inserindo, como nos ensina Deleuze (2015, p. 223), “[...] o afeto como avaliação imanente no lugar do juízo como valor transcendente". Com base em Nietszche, Deleuze (2015) ressalta que o mau é a vida esgotada, degenerativa; e o bom, a vida efusiva, a que sabe metamorfosear-se mediante as forças que compõem com ela um poder crescente, que aumenta a potência de ação, o poder da vida, abrindo novos possíveis e (in)possíveis.

O mundo vive em nosso corpo sob o modo de afectos e perceptos. Portanto, os afectos e perceptos compõem nossas vidas, bem como impulsionam o processo incessante de reinvenção de nós mesmos e de nosso entorno. As imagens do curta Alike produzem novas afecções, desestabilizam a subjetividade, provocam inquietação, impondo ao desejo uma vontade de potência, uma necessidade de novos modos de existência. Dessa forma, a micropolítica reativa visa à conservação do status quo, do pensamento dogmático; já a micropolítica ativa busca a conservação da potência do vivo, que se constitui em um incessante processo de construção da realidade (ROLNIK, 2016).

É comum, nos encontros das professoras com as imagens cinematográficas, fazer disparar, por meio das redes de conversas, os infinitos questionamentos a respeito das verdades universais fixadas às escolas, à docência e aos desafios de compor novos planos, novas montagens, fazer enquadres e desenquadres, de permitir ao corpo se agenciar e deslizar junto aos devires-imagens, aos devires-conversas:

\footnotetext{
"A gente vai inventando um monte de possibilidades com as crianças para que elas possam experimentar o corpo, e aí vem alguém e questiona: será que pode ser assim? Será que podemos apresentar isso no dia da apresentação dos projetos científicos? E, assim, as nossas invencionices, as invencionices das crianças, tudo o que criamos com as crianças precisa ser formatado com os crivos daqueles que dizem o que as escolas de educação infantil precisam ensinar, mas nem imaginam o mundo de acontecimentos que explode por aqui! E tudo que inventamos a partir desses acontecimentos".
} 
A nossa aposta é nos acontecimentos, no que suscita dos encontros das professoras com as imagens cinematográficas, nas redes de conversas que as imagens promovem. É, portanto, na força que se constitui no/do coletivo que fortalece a vontade de potência ${ }^{10}$ (NIETSZCHE, 2010). Muitas vezes os encontros com as imagens-cinema causam incômodo, estranhamento, mas incômodo é inquietação, provocação, é movimento de pensamento suscitado pelas diferenças de crenças, de verdades, de ideias.

Os encontros com as imagens-cinema possibilitam, sobretudo, por meio das conversas, das trocas de experiências, dos conflitos de ideias, a invenção de novos sentidos para a educação infantil e, assim, a criação de novas praticaspolíticas para a educação.

\begin{abstract}
"Eu fiquei emocionada com o filme Alike. Até chorei. Aquela parte em que o menino escuta o som da música do violino e mostra-se encantado com o músico me afeta. Nós temos que prestar mais atenção nos interesses das crianças, o que ela está querendo aprender, como quer aprender, ajudá-la a fazer seus projetos. Os adultos precisam valorizar mais as invenções das crianças".

"Muitas vezes a gente acaba vivendo essa vida pelo peso que a gente carrega de ter que ensinar, de fazer a criança produzir, por essa responsabilidade, ou mesmo para fazer bonito para o pai ver, para a sociedade ver, para ser mostrado. Assim, a gente ignora essa parte leve e boa que deve ser a infância e sobrecarrega a criança de responsabilidades. Com isso nos tornamos amargos, sem cor. Nós, que trabalhamos com esse público tão leve que são as crianças, como a gente pode se tornar mais colorido e mais leve também?"
\end{abstract}

Como disse a poeta professora, que venha o outono e, junto com ele, mais possibilidades de nos escutarmos melhor. Que tenhamos mais espaços e tempos para que professoras, alunos/as e todos/as que fazem as escolas todos os dias tenham oportunidades de viver de forma mais inventiva. O curta-metragem Alike, utilizado como disparador para as nossas redes de conversações com as professoras, possibilitou que uma multiplicidade de praticasdiscursivas engendradas nas redes de poderes, saberes e de subjetividades fossem explicitadas e repensadas. Assim, as "verdades" que ao longo dos séculos vêm sendo produzidas "para" as escolas, "para" as docências e "para" as infâncias foram desterritorializadas e reterritorializadas. Nesse sentido, novos modos de pensar as aprendizagens e as invencionices das escolas foi se constituindo, junto com os currículos criados a partir dos encontros e das relações estabelecidas com as imagens desse curta-metragem.

Para Deleuze (2015), o cinema é o único dispositivo capaz de nos oferecer uma percepção direta do tempo. O tempo opera tanto na filosofia, como na arte e no cinema, colocando em crise a

10 Força que se constitui no coletivo em busca da produção dos possíveis. Afirmação da vida intensiva e inventiva. 
verdade e o mundo, a significação e a comunicação. A contemporaneidade nasce da crise da representação, posicionando, em primeiro plano, a criação do novo. O novo é a linha de fuga, o que escapa da representação é a possibilidade de fabular, imaginar no mundo da razão. Bergson, citado por Parente (2007, p. 11), ressalta: “[...] Ou o tempo é invenção, ou ele não é nada. O tempo é processo, portanto, atualiza-se, desdobra-se".

O curta-metragem Alike, como tantos outros "bons encontros" (SPINOZA, 2014) realizados com as imagens nas escolas, possibilita a dobra no/do pensamento das professoras deformando as formas dos currículos (PARAÍSO, 2015), suscitando os afetos alegres e forças ativas para o devir docência produzir nonos movimentos curriculares. Em que condições as imagens promovem o arroubo do pensamento? Zourabichvili (2016) afirma que a relação é contigente, casual. Assim, um encontro é sempre inexplicável e o pensar nasce de um acontecimento. Nos encontros com as imagens cinematográficas, colocamos o pensamento disponível para a conexão efetiva com o fora, com o (in)pensado, com o (in)possível.

O encontro com o curta Alike foi um novo ar para as professoras, fez movimentar o pensamento, ajudando-as a buscar novos sentidos para as suas práticas, a experimentar e inventar novas combinações curriculares e outros modos de ser e de estar nas escolas. Possibilitou refletir sobre a importância de acompanhar os fluxos inventivos das infâncias, a entrar no jogo das fabulações infantis que nos fazem escapar dos engessamentos, das normatizações.

A força das imagens do curta Alike rompe como fluxo intensivo, possibilitando o intempestivo que expande a potência de ação coletiva e o deslizar do pensamento nômade. Os devires, que pedem passagem por meio da imagem-cinema que desaloja o pensamento, permitem o encontro com as diferenças que habitam os cotidianos da educação infantil. As professoras, diante das perguntas, dos conflitos de ideias, das trocas de experiências, reacendem a vontade de potência, multiplicando-se entre os desejosos devires, dizendo sim para a vida.

Finalizamos, provisoriamente, com algumas das enunciações das professoras sobre a potência das imagens cinematográficas nos encontros de formação:

"As imagens cinematográficas despertam diferentes sensações, emoções. Atuam como estopins, fazem sentir e pensar. Os curtas apresentados nos levaram a pensar as experiências nas formas de retratar a vida, nos pontos de convergência e distanciamento da realidade".

"Assistir filmes com a possibilidade de verbalizarmos a forma como as imagens nos afetam, de trocarmos experiências com os colegas de escola nos permite repensar a nossa prática nos aproximando do outro e de suas questões, contribuindo com o fortalecimento individual e, principalmente, coletivo". 
“As imagens cinematográficas fazem-nos escapar daquilo que nos é imposto. Possibilitam pensar as nossas incertezas e inquietações, o cotidiano da escola e da vida. Fortalecem a coletividade".

Essas narrativas se articulam com a problematização de Zourabichvili (2016, p. 70): "Por que a teoria do sentido e do pensamento tem necessidade de uma lógica das forças?’. Porque o pensar nasce de conexões, encontros, relações. Porque não se pensa sem ser sensível aos signos. Porque não se faz educação sem pesquisa, sem investigação, sem investimento, sem aposta coletiva, sem criação. Porque não existe educação sem diferença. Por mais encontros, por mais afetos, por mais conversas nas escolas, por mais desejo coletivo!

\section{REFERÊNCIAS}

ALVES, N. Cultura e cotidiano escolar. Revista Brasileira de Educação, n. 23, p. 62-74, maio/ago. 2003.

CARVALHO, J. O cotidiano escolar como comunidade de afetos. Petrópolis, RJ: DP et Alii, Brasília, DF: CNPq, 2009.

Cartografia e cotidiano escolar. In: FERRAÇO, C.E.; PEREZ, C. L. V.; OLIVEIRA, I. B. Aprendizagens cotidianas com a pesquisa: novas reflexões em pesquisa nos/dos/com os cotidianos. Petrópolis, RJ: DP et Alii, 2008.

CARVALHO, J. M.; SILVA, S. K.; DELBONI, T. M. Z. G. F. Nos fluxos da vida intensiva e inventiva das escolas: em busca de outros modos de existência para a nova Terra. Revista Linha Mestra, n. 35, p. 46-51, maio/ago. 2018.

DELEUZE, G. A imagem-tempo: cinema 2. Tradução de Souza Dias. Lisboa, Portugal: Documenta, 2015.

. A imagem-movimento: cinema 1. Tradução de Souza Dias. Lisboa, Portugal: Documenta, 2016.

. Conversações. Tradução de Peter Pál Pelbart. São Paulo: Editora 34, 2010.

. Crítica e clínica. Tradução de Peter PálPelbart. São Paulo: Editora 34, 2011.

. Diferença e repetição. Tradução de Luiz Orlandi e Roberto Machado. Rio de Janeiro: Graaal, 2006.

. O mistério de Ariana. Tradução de Edmundo Cordeiro. Lisboa: Ed. Veja-Passagens, 1996.

DELEUZE, G. Proust e os signos. Tradução de Antônio Picquet e Roberto Machado. Rio de Janeiro: Forenze Universitária, 2003.

DELEUZE. G.; GUATTARI, F. Mil platôs: capitalismo e esquizofrenia. Tradução de Aurélio Guerra Neto, Ana Lúcia de Oliveira, Lucia Cláudia Leão e Suely Rolnik. São Paulo: Editora 34, 2011. v. 1.

. Mil platôs: capitalismo e esquizofrenia. Tradução de Aurélio Guerra Neto, Ana Lúcia de Oliveira, Lucia Cláudia Leão e Suely Rolnik. São Paulo: Editora 34, 2012. v. 3.

GALLO, S. Algumas notas em torno da pergunta: o que pode a imagem? In: DE CAMARGO, M. R. R. M.; LEITE, C. D. P.; CHALUH, L. N. Linguagens e imagens: educação e políticas de subjetivação. Petrópolis/RJ: De Petrus et Alii, 2014.

KOHAN, W. O. Infância: entre educação filosofia. Belo Horizonte: Autêntica, 2005.

MACHADO, R. Deleuze, a arte e a filosofia. Rio de Janeiro: Ed. Jorge Zahar, 2009. 
NIETSZCHE, F. W. Assim falou Zaratustra: um livro para todos e para ninguém. Rio de Janeiro: Civilização Brasileira, 2010.

OLIVEIRA, I. B. de; SBARBI, P. Estudos do cotidiano \& Educação, Belo Horizonte, Autêntica Editora, 2008.

PARAÍSO, M. Um currículo entre formas e forças. Revista Educação, Porto Alegre, v. 38, n. 1, p. 49-58, jan./abr. 2015.

PARENTE, A. Cinema em trânsito: do dispositivo do cinema ao cinema do dispositivo. In: PENAFRIA, M.; MARTINS, I. M. (org.). Covilhã: Estéticas do digital: cinema e tecnologia, 2007.

SPINOZA, B.de. Ética. Tradução de Tomás Tadeu. Belo Horizonte: Editora Autêntica, 2014.

ROLNIK, S. A hora da micropolítica. São Paulo: n-1 Edições, 2016.

Esferas da insurreição: notas para uma vida não cafetina. São Paulo: n-1Edições, 2018.

ZOURABICHVILI, F. Deleuze: uma filosofia do acontecimento.Tradução de Luiz B. L. Orlandi. São Paulo: Editora 34, 2016. 


\section{AS IMAGENS-CINEMATOGRÁFICAS COMO FORÇA QUE IMPULSIONA O DEVIR-PENSAMENTO NO COTIDIANO ESCOLAR}

Resumo: Este artigo problematiza o que pode a imagem?, questionando se o "uso" das imagens cinematográficas provoca rupturas no pensamento dogmático e favorece a passagem para o pensamento nômade habitar o "plano de imanência" do corpoescola. Apresenta resultados de uma pesquisa que produziu uma cartografia das forças que se engendram em redes de conversação provocadas nos encontros das professoras com as imagens cinematográficas. Em diálogo com Deleuze e Spinoza, o artigo argumenta que o encontro com as imagens cinematográficas em redes de conversações com as professoras provoca afecções e afetos que possibilitam o movimento de pensamentos, expandindo, assim, as forças ativas, a potência de ação coletiva, os processos de formação inventiva e os movimentos curriculares.

Palavras-chave: Imagens-cinema. Redes de conversações. Cotidiano escolar.

\section{CINEMATOGRAPHIC IMAGES AS THE DRIVING FORCE FOR THE BECOMING-THOUGHT IN EVERYDAY SCHOOL}

Abstract: This paper discusses what an image is able to do, questioning whether the "use" of cinematographic images can cause ruptures regarding the dogmatic thought and can favor the passage for the nomadic thought to inhabit the "immanence plan" from school-body. The article presents the results of a research that has produced a mapping of the forces that were engendered within conversation networks provoked during meetings with Teachers and the cinematographic images. In dialogue with Deleuze and Spinoza the article argues that the meeting between the cinematographic images and Teachers in conversation networks causes affections, which enable the movement of thoughts, thus, expanding, active forces, collective action potency, inventive formation processes and curricular movements.

Keywords: Cinema-images. Conversation networks. Every Day school.

\section{LAS IMÁGENES-CINEMA COMO FUERZA QUE IMPULSIONA EL DEVIR-PENSAMIENTO DEL COTIDIANO ESCOLAR}

Resumen: Este artículo problematiza la siguiente cuestión: cual es el poder de la imagem?, indagamos si el "uso" de las imágenes cinematográficas provoca rupturas en el pensamiento dogmático y favorece pasar para el pensamiento nómada habitar en el "plano de inmanencia" del cuerpoescuela. Trae resultados de una investigación que produjo una cartografia de las fuerzas que se engendran en redes de conversaciones provocadas en los contactos de las professoras con las imágenes-cinema. Dialogando con Deleuze y Spinoza, el artículo sustenta que el contacto con las imágenes cinematográficas en redes de conversaciones con las professoras provoca afecciones y afectos que posibilitan movimientos de pensamiento, ampliando, así, las fuerzas activas, la potencia de la acción colectiva, los processos de formación inventiva y los movimentos curriculares.

Palabras-llave: Imágenes-cinema. Redes de conversaciones. Cotidiano escolar.

Submetido em Julho de 2019

Aprovado em Novembro de 2019

Revista Teias v. $20 \bullet$ n. 59 • out/dez 2019 • Outras epistemologias e metodologias nas investigações sobre currículo 300 